\title{
DNA damage induces nuclear translocation of parkin Shyan-Yuan Kao
}

\author{
Address: Eaton Peabody Laboratory, Massachusetts Eye and Ear Infirmary, 243 Charles Street, Boston MA 02114. USA \\ Email: Shyan-Yuan Kao - shyan-yuan_kao@meei.harvard.edu
}

Published: 17 July 2009

Journal of Biomedical Science 2009, 16:67 doi:10.1/86/1423-0/27-16-67

This article is available from: http://www.jbiomedsci.com/content/16/l/67

(C) 2009 Kao; licensee BioMed Central Ltd.

This is an Open Access article distributed under the terms of the Creative Commons Attribution License (http://creativecommons.org/licenses/by/2.0), which permits unrestricted use, distribution, and reproduction in any medium, provided the original work is properly cited.
Received: 15 May 2009

Accepted: 17 July 2009

\begin{abstract}
Parkinson's disease (PD) is the second most common form of human degenerative disorder. Mutation of parkin is one of the most prevalent causes of autosomal recessive PD. Parkin is an E3 ubiquitin ligase that acts on a variety of substrates, resulting in polyubiquitination and degradation by the proteasome or monoubiquitination and regulation of biological activity. However, the cellular functions of parkin that relate to its pathological involvement in PD are not well understood. Here I show that parkin translocates into nucleus upon DNA damage. Nuclear translocation of parkin appears to be required to promote DNA repair. These findings suggest that DNA damage induces nuclear translocation of parkin leading to the PCNA interaction and possibly other nuclear proteins involved in DNA repair. These results suggest that parkin promotes DNA repair and protects against genotoxicity, and implicate DNA damage as a potential pathogenic mechanism in parkinsonism.
\end{abstract}

\section{Introduction}

Parkin was first isolated as the candidate gene of autosomal recessive juvenile Parkinsonism (AR-JP) [1]. Although many types of mutations, such as point mutations, truncations and/or splicing variants of parkin, are found in Parkinson's disease (PD) patients [2], the mechanism of how parkin is involved in PD remains elusive. In addition to its association with PD, parkin might be associated with carcinogenesis and may be a tumor suppressor [3]. Abnormal parkin transcripts have been detected in a number of different tumor cell types, including lung, cervical, pancreatic, and kidney tumors [3].

Parkin functions as an E3 ubiquitin protein ligase [1]. Based on its structure, parkin may act as a docking station bringing substrate proteins to an E2 ubiquitin conjugating enzyme for ubiquitination, thus leading to their degradation [4]. Several parkin interacting proteins have been identified, including CDCrel-1 [5], glycosylated $\alpha$-synuclein [6], synphilin-1 [7], PAEL-R [8], cyclin E [9], ami-
noacyl-tRNA synthetase cofactor p38 [10], and a PDZ containing protein CASK/Lin2 [11]. However, the mechanism by which parkin mutations cause PD remains to be determined.

Accelerated DNA damage occurs during the aging of the human brain [12]. Furthermore, several studies suggest that DNA damage is involved in neurodegenerative processes $[13,14]$. For example, the level of the DNA damage marker, 8-hydroxyguanine is increased in genomic DNA in PD substantia nigra compared to non-PD controls [15]. In addition, somatic mitochondrial DNA mutations in cortex and substantia nigra are increased in PD [16]. Furthermore, it has been proposed that oxidative stress induced DNA damage could be an important risk factor for PD $[17,18]$.

These observations prompted us to examine genes associated with PD for a role in DNA damage response. The current studies provide evidence that DNA damage promotes 
nuclear translocation of parkin. These findings provide a potential interface between normal aging associated DNA damage and pathologic associated with neurodegenerative disease, and is consistent with the very early onset of PD associated with parkin mutations.

\section{Materials and methods Antibodies}

Rabbit anti-Parkin antibodies and rabbit anti- $\beta$-actin antibodies were purchased from Cell Signaling. Mouse antiPCNA antibodies were from Santa Cruz Biotechnology. Goat anti-8-OHdG antibodies and mouse anti-lamin B antibodies were obtained from Chemicon, and mouse anti-CPD was from MBL.

\section{Cells and tissues}

SH-SY5Y human neuroblastoma cells and HeLa cells were grown in DMEM supplemented with 10\% fetal bovine serum. Parkin and parkin mutant (Del 3-4) stable cells were established by transfecting pcDNA3.1(-)-Parkin or pcDNA3.1(-)-Parkin-Del 3-4 into SY5Y cells, and selected by geneticin. Post-mortem human cortical samples were described previously [12].

\section{Chromatin immunoprecipitation}

The association of parkin with calmodulin 1 promoter was assayed by chromatin immunoprecipitation (ChIP) using the ChIP assay protocol (Upstate) with some modifications. Brain tissue samples were prepared as described before [12]. HeLa cells transfected with parkin and UV damaged or undamaged calmodulin promoter constructs was harvested according to ChIP assay protocol. The amount of DNA in the resulting cell lysates was quantified by measuring absorption at $260 \mathrm{~nm}$, and then adjusted to $100 \mu \mathrm{g} / \mu \mathrm{l}$. $200 \mu \mathrm{g}$ supernatant was diluted 10-fold in $2 \mathrm{ml}$ ChIP dilution buffer (0.01\% SDS, 1.1\% Triton X-100, 1.2 mM EDTA, $16.7 \mathrm{mM}$ Tris- $\mathrm{HCl}, \mathrm{pH} 8.1,167 \mathrm{mM} \mathrm{NaCl}$, and protease inhibitors), and precleared twice with BSAblocked Protein L Agarose (Pierce) $(2 \times 100 \mu \mathrm{g}, 2 \times 30 \mathrm{~min}$ at $4^{\circ} \mathrm{C}$ ). The beads were centrifuged and the supernatant was divided into $4 \times 500 \mu \mathrm{l}$ aliquots for immunoprecipitation, input DNA, and the IgG control. Primary antibody was added and incubated at $4{ }^{\circ} \mathrm{C}$ overnight. A rabbit antiparkin polyclonal antibody (Cell signaling) was used for immunoprecipitation of Parkin, and ChromPure rabbit IgG (Jackson ImmunoResaerch) was used for the IgG con-

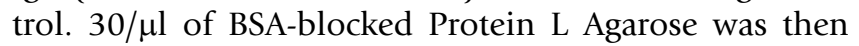
added and incubated at $4{ }^{\circ} \mathrm{C}$ with rotation. The beads were then centrifuged and washed once with a low salt immune complex buffer (Upstate), twice with a high salt wash buffer, once with a $\mathrm{LiCl}$ wash buffer (Upstate), and twice in TE buffer (10 mM Tris-HCl, $1 \mathrm{mM}$ EDTA, pH 8.0). The washed agarose beads were eluted with $2 \times 250 \mu$ l freshly prepared elution buffer (1\% SDS, $0.1 \mathrm{mM} \mathrm{NaHCO} 3$ ). DNA crosslinking was reversed by adding $5 \mathrm{M} \mathrm{NaCl}$ and heating at $65^{\circ} \mathrm{C}$ for 4 hrs. Protein was removed by incubation with $20 \mathrm{mg} / \mathrm{ml}$ proteinase $\mathrm{K}$ in $10 \mu \mathrm{g}$ EDTA/40 mM Tris-HCl, pH 6.5 for $1 \mathrm{hr}$ at $45^{\circ} \mathrm{C}$. De-crosslinked DNA was then isolated by phenol/chloroform extraction and ethanol precipitation. The precipitated DNA was washed with $70 \%$ ethanol, air dried and dissolved in $\mathrm{ddH}_{2} \mathrm{O}$ for PCR.

\section{Induction of DNA damage}

UV-irradiation was performed by irradiating SH-SY5Y cells with UV-C light $\left(254 \mathrm{~nm}, 60 \mathrm{~J} / \mathrm{m}^{2}\right)$ using a Stratalinker (Stratagene). Oxidative DNA damage was performed on SH-SY5Y cells treated with $\mathrm{H}_{2} \mathrm{O}_{2}(300 \mu \mathrm{M})$ for overnight. Double strand break DNA damage was induced by treatment with $50 \mu \mathrm{M}$ etoposide (Calbiochem) for overnight.

\section{Immunohistochemical staining of DNA cyclopyrimidine dimers (CPD)}

Immunohistochemical staining of CPD was performed after irradiating SH-SY5Y cells with $100 \mathrm{~J} / \mathrm{M}^{2}$ of $254 \mathrm{~nm}$ UV light using a microfliter (Millipore). Cells were then fixed $1 \mathrm{hr}$ or $12 \mathrm{hr}$ later with 4\% paraformaldehyde, permeabilized for $15 \mathrm{~min}$ in $0.4 \%$ Triton X-100 (Sigma) in PBS, and the DNA was denatured in $2 \mathrm{M} \mathrm{HCl}$ for $30 \mathrm{~min}$ at room temperature. After blocking with FBS, cells were incubated with anti-CPD antibody (1:3000) for $30 \mathrm{~min}$. The sections were then incubated with Cy3-conjugated anti-goat IgG (Jackson ImmunoResearch) at room temperature for $30 \mathrm{~min}$ and then with Hoechst dye for $5 \mathrm{~min}$. The sections were analyzed by fluorescence transmission or confocal microscopy.

\section{Host cell reactivation assays}

The host cell reactivation assay (HCR) was performed as described previously $[19,20]$. A pTK-Renilla reporter plasmid was damaged by exposure to UV-C light $(254 \mathrm{~nm})$ at $250 \mathrm{~J} / \mathrm{m}^{2}$ in vitro, which markedly reduces its expression. SH-SY5Y cells were then transfected with UV-irradiated or control non-irradiated pTK-Renilla expression vectors. Each plate was co-transfected with a control firefly luciferase vector (pGL3-basic) to control for transfection efficiency. Cells lysis was performed 24 hours after transfection, renilla and firefly luciferase activities were measured, and renilla luciferase activity was normalized to the firefly luciferase activity in the same plate. Renilla luciferase activity of the control undamaged plasmid was normalized to $100 \%$, and compared with the expression of the UV-irradiated reporter plasmid in the same cell type.

\section{Results \\ DNA damage and nuclear translocation of parkin}

I first asked if parkin is translocated to the nucleus upon DNA damage. To assess nuclear translocation, SH-SY5Y 
cells stably over-expressing parkin were analyzed by subcellular fractionation after exposure to agents that induce DNA damage. Cell lysates were separated into nuclear and cytoplasmic fractions, and parkin was resolved by immunoblotting (Fig 1, top). The ratio of nuclear to cytoplasmic parkin was significantly increased after UV irradiation, treatment with $\mathrm{H}_{2} \mathrm{O}_{2}$, and treatment with etoposide, which selectively induces DNA double strand breaks (Fig $1 \mathrm{~A}$, bottom). Absence of cross-contamination of the fractions was confirmed by immunoblotting for lamin B, a nuclear marker, and $\beta$-actin, a cytoplasmic marker. Thus, a variety of different DNA damaging insults can induce the nuclear translocation of parkin.

The nuclear translocation of parkin was confirmed by immunofluorescence assays. SH-SY5Y cells stably overexpressing parkin were irradiated by UV-C light $\left(60 \mathrm{~J} / \mathrm{M}^{2}\right)$. The nuclear translocation of parkin was assayed $2 \mathrm{hr}$ after treatment. Parkin expression was mainly cytoplasmic without UV irradiation (Fig 1B, top), while the expression of parkin in the nucleus was greatly increased after UV irradiation (Fig 1B, bottom). These results confirmed the nuclear translocation of parkin after DNA damage.

\section{Parkin associates with damaged DNA}

To further explore whether parkin is involved in DNA damage repair, I examined whether parkin associated with damaged DNA. A human calmodulin 1 promoter construct was either UV irradiated in vitro or untreated, and then was co-transfected with a parkin construct into HeLa cells. The human calmodulin 1 promoter was chosen because it was preferentially damaged in human ageing brain [12], and the HeLa cell line was used because HeLa cells contain a parkin gene deletion [21] and may not express functional parkin protein [22,23]. ChIP assays were performed to determine the association between parkin and DNA. There was a weak interaction between parkin and untreated calmodulin 1 promoter (Fig. 2A), however such interaction was significantly increased when DNA was damaged by UV irradiation (Fig. 2A).

To demonstrate that parkin associated with damage DNA also occurred in human brain tissues with endogenous damaged DNA, I next investigated the association between parkin and the endogenous calmodulin 1 promoter in normal human brain tissues. After analyzing tissue samples from 4 young brains (<40-year-old) and 4 old brains ( $>70$-year-old), ChIP assays showed a much stronger association between parkin and calmodulin 1 promoter in the aged brain tissues than that in young brain tissues (Fig. 2B). Since there were higher levels of DNA damage in aged human brains as shown by the presence of high level of 8-OHdG in calmodulin 1 promoter (Fig. 2B, bottom), these results suggest that parkin is associated with damaged DNA in vivo.

\section{Parkin reduces DNA damage induced by UV irradiation}

Since parkin associates with damaged DNA complex, this observation prompted me to ask whether parkin is involved in the process of DNA repair. To address this question, DNA damage was induced by UV irradiation of SH-SY5Y cells that stably over-express wild-type parkin or control expression plasmids. DNA damage was examined by immunofuorescence microscopy with an antibody to cyclobutane pyrimidine dimers (CPD), a major DNA adduct induced by UV irradiation. UV irradiation induced substantial DNA damage in all three cell lines as indicated by robust nuclear immunoreactivity for CPD (Fig. 3, top, $1 \mathrm{hr}$ post-treatment). This damage was markedly reduced by over-expression of wild-type parkin after $12 \mathrm{hr}$ (Fig. 3, top, 12 hr post-treatment). In contrast, over-expression of a parkin exon 3-4 deletion construct, which is associated with autosomal recessive PD, did not appear to reduce UV-induced CPD immunoreactivity (Fig 3, top, $12 \mathrm{hr}$ post-treatment, and bottom).

\section{Nuclear localized parkin promotes DNA excision repair}

In a previous study, I have shown that parkin interacts with proliferating cell nuclear antigen (PCNA), and promotes DNA excision repair [24]. I next tested whether nuclear translocation is important for the promotion of DNA excision repair by parkin. Host cell reaction assays were used to determine the ability of parkin to promote nucleotide excision repair. I found that the over-expression of parkin could facilitate DNA repair. In the HCR assays, UV damaged or control renilla reporter constructs were transfected into SH-SY5Y cells together with parkin expression constructs, parkin Del 3-4, or vector backbone pcDNA3.1. Wild type Parkin transfected cells had approximate 30\% higher cellular DNA repair activity than mocktransfected cells (Fig. 4A), while the Parkin Del 3-4 mutant had little effect on DNA repair. This result indicates that Parkin facilitates DNA repair induced by UV irradiation.

Parkin is shown to be localized dominantly cytoplasm with some fraction of parkin expressed in mitochondria and nucleus. To further explore the importance of nuclear translocation and regulation of DNA repair by parkin, several parkin expressing plasmids were constructed. The nuclear localization signal (NLS) of SV40 large T antigen [25] and the nuclear export signal (NES) of HIV Rev [26] were inserted upstream of parkin coding sequences respectively so that parkin can be localized exclusively in either cell nucleus (Parkin-NLS) or cytoplasm (ParkinNES) in SH-SY5Y cells. I next tested the ability of these constructs to regulate DNA repair activity. Using HCR assays, wild type Parkin and Parkin-NLS facilitate DNA repair more than 30\% compared to control cells (Fig. 4B), while Parkin-NES had little effect on DNA repair, indicat- 
(A)
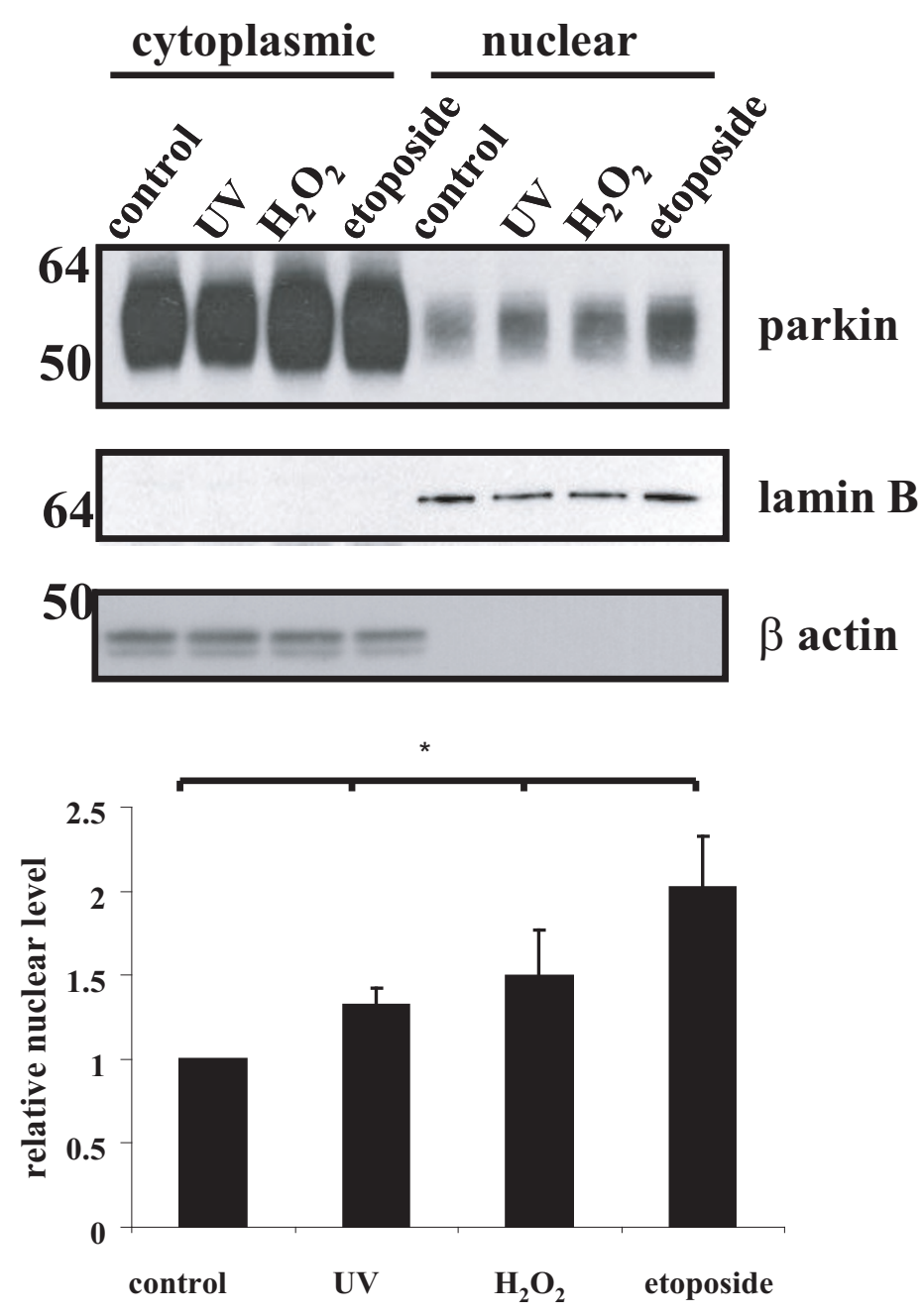

(B)
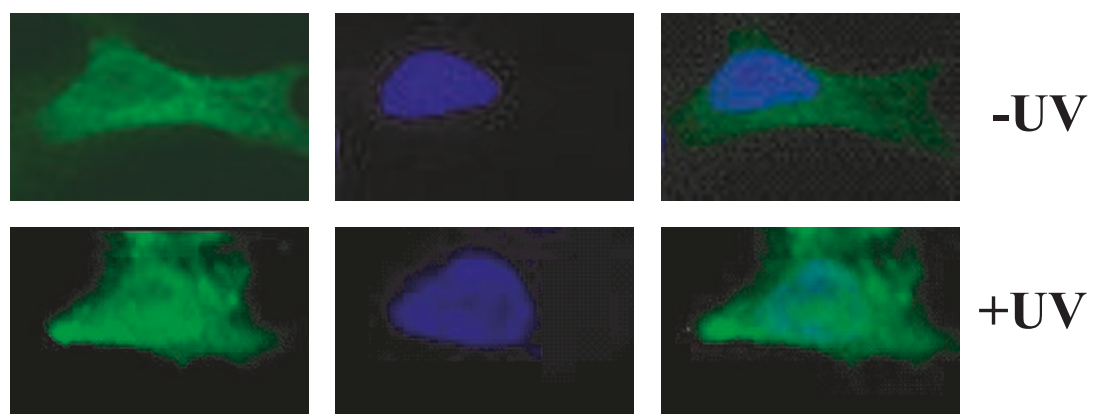

parkin Hoechst merge

Figure I (see legend on next page) 
Figure I (see previous page)

DNA damage and nuclear translocation of parkin. (A) DNA induces nuclear translocation of parkin. SH-SY5Y cells stably transfected with parkin were UV-irradiated $\left(60 \mathrm{~J} / \mathrm{m}^{2}\right)$, or treated with $\mathrm{H}_{2} \mathrm{O}_{2}(300 \mu \mathrm{M})$ or etoposide (50 $\left.\mu \mathrm{M}\right)$ to induce DNA damage, followed by the isolation of nuclear and cytoplasmic fractions and resolution of parkin by immunoblotting. Note that each DNA damaging agent induced an increase in the absolute and relative levels of parkin in the nucleus. Absence of crosscontamination of the fractions was confirmed by immunoblotting for lamin $B$, a nuclear marker, and $\beta$-actin, a cytoplasmic marker. Quantitation of the relative nuclear ratio of parkin is shown, and represents the mean \pm S.D., $n=3$. $* P<0.05$ relative to control by ANOVA with post-hoc Student Neumann-Kiels tests. (B) Nuclear translocation of parkin in SH-SY5Y cells was confirmed by immunofluorescence assays. SH-SY5Y cells stably over-expressing parkin were UV-irradiated $\left(60 \mathrm{~J} / \mathrm{m}^{2}\right)$ or $\mathrm{mock}$ treated. Two hours later the cellular localization of parkin was determined by immunofluorescent microscopy. Green: parkin. Blue: Hoechst staining of nucleus.

(A)

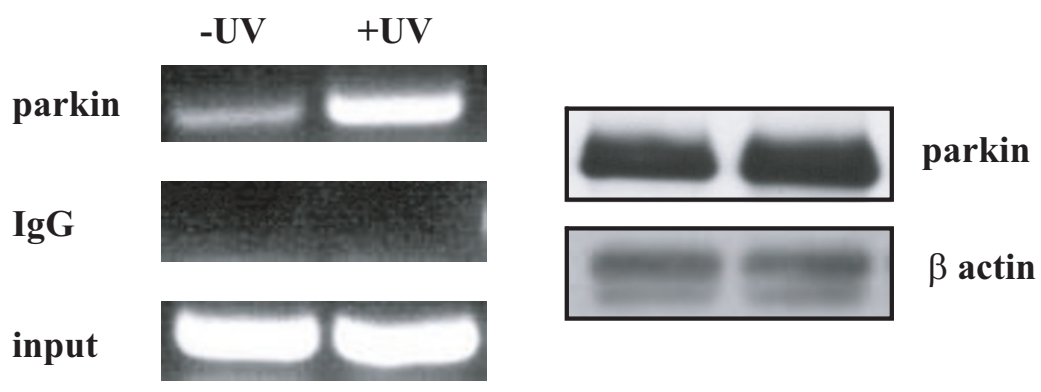

ChIP immunoblot

(B)

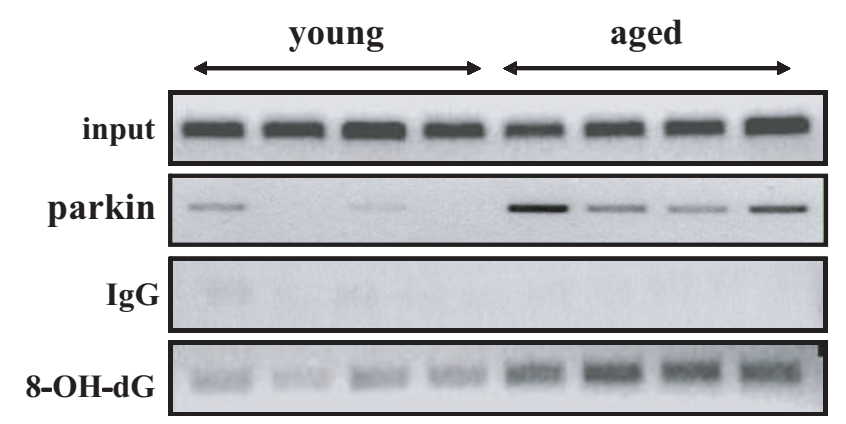

\section{Figure 2}

Parkin interacts with damaged DNA. (A) Parkin was co-transfected in HeLa cells with a calmodulin I promoter construct under control conditions (-UV) or after the calmodulin construct was damaged by UV irradiation in vitro (+UV)(I00 J/M2). To determine whether parkin interacts with damaged DNA, parkin was immunoprecipitated followed by PCR amplification of the calmodulin promoter construct. Note the markedly increased co-precipitation of parkin with DNA damaged by UV irradiation. Input DNA, non-specific IgG controls, and parkin, $\beta$-actin immunoblots are shown. (B) Parkin binds to chromatin in the aging human brain. ChIP assays were performed on postmortem human cortical samples with anti-parkin or anti-8-oxoguanine followed by PCR amplification of a calmodulin-I promoter sequence that is damaged in human cortical samples from aged and young adult individuals. Note increased binding of parkin to chromatin from some aged cortical samples ( $\geq 73$ years old) relative to young adult samples ( $<40$ years old), which correlates with increased 8 -oxoguanine content. Input and non-specific lgG ChIP controls are shown. 


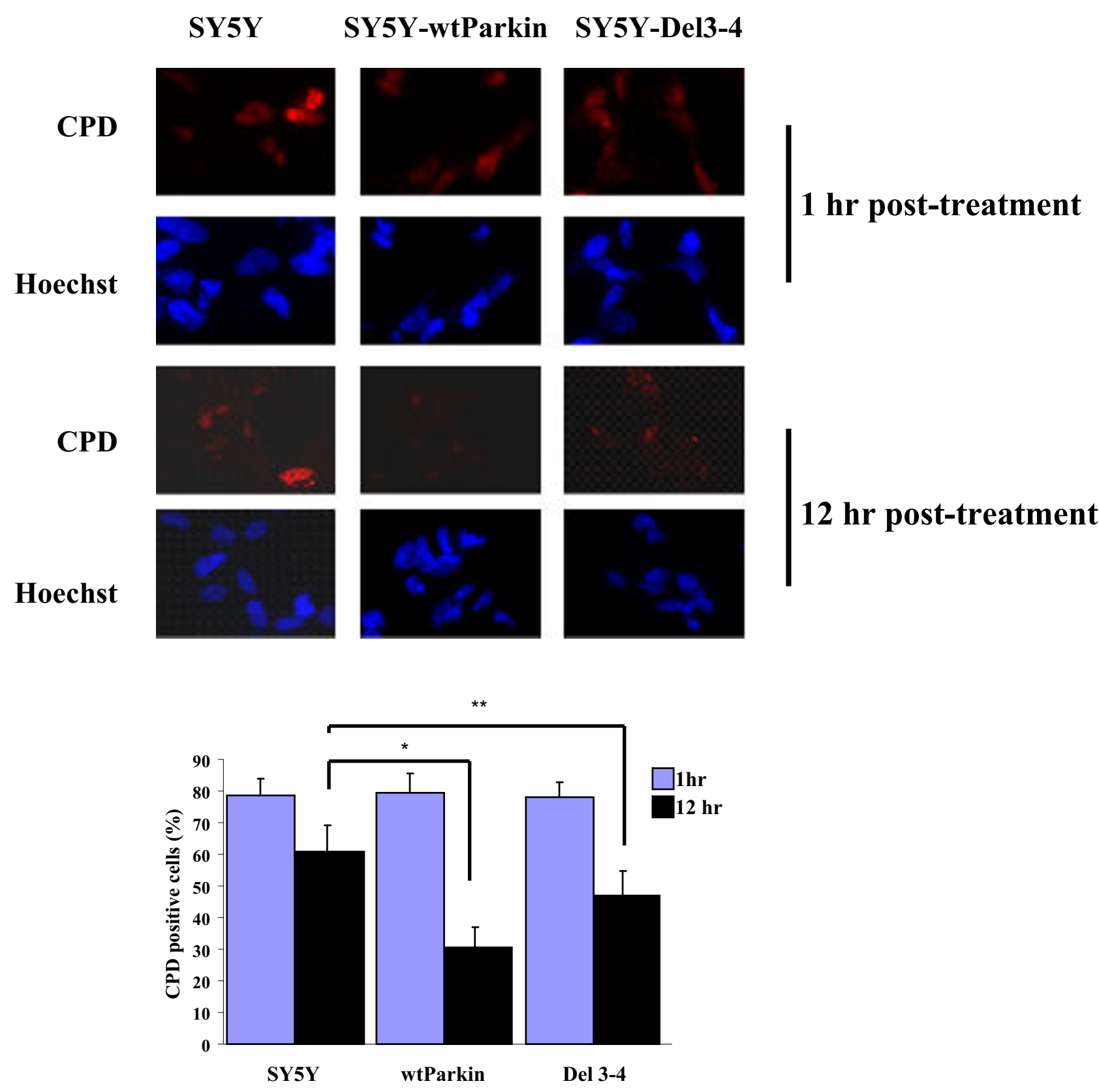

\section{Figure 3}

Parkin reduces DNA damage induced by UV irradiation. Stably SH-SY5Y cell lines expressing wild-type parkin, the Del3-4 parkin mutant, or the pcDNA control vector were UV-irradiated $\left(100 \mathrm{~J} / \mathrm{M}^{2}\right)$ and then assessed for DNA damage by immunocytochemical staining for cyclopyrimidine dimers (CPD) (red). Nuclei were stained with Hoechst dye. All three cell lines show similar robust CPD staining I hr after UV irradiation. Decreased DNA damage in SH-SY5Y cells expressing parkin, but not the pcDNA control and Del3-4 parkin mutant was detected. Quantitation of CPD positive cells in three cell lines after UV irradiation is shown, and represents the mean \pm S.D., $n=5$. $* P<0.05$, $* * p>0.05$ relative to control by ANOVA with posthoc Student Neumann-Kiels tests. 
(A)
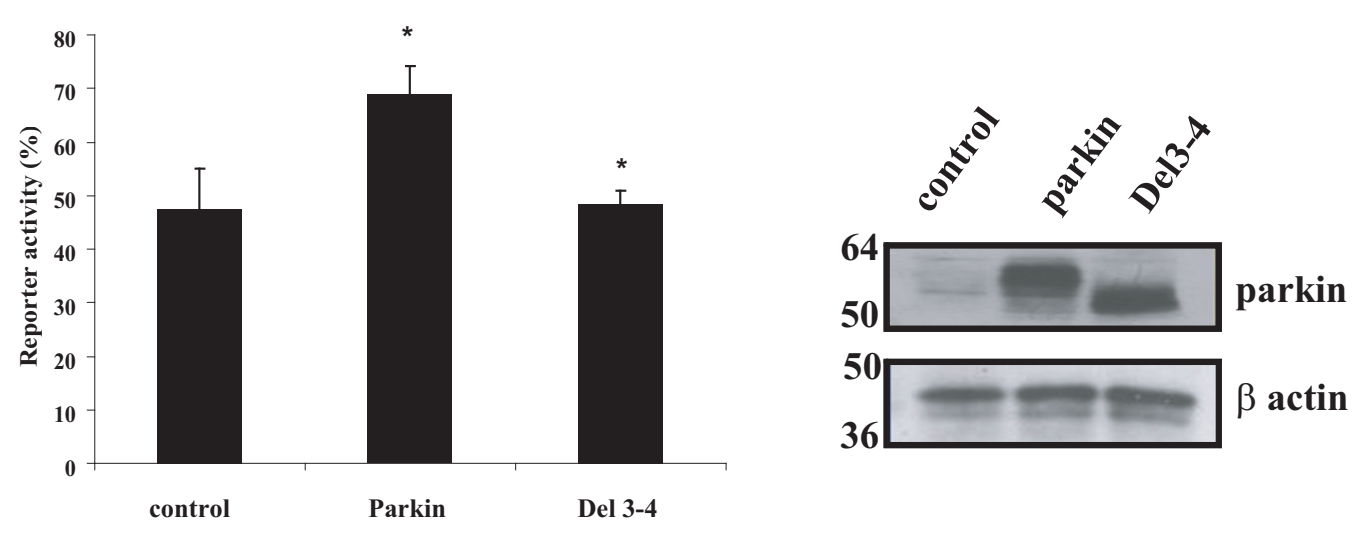

(B)
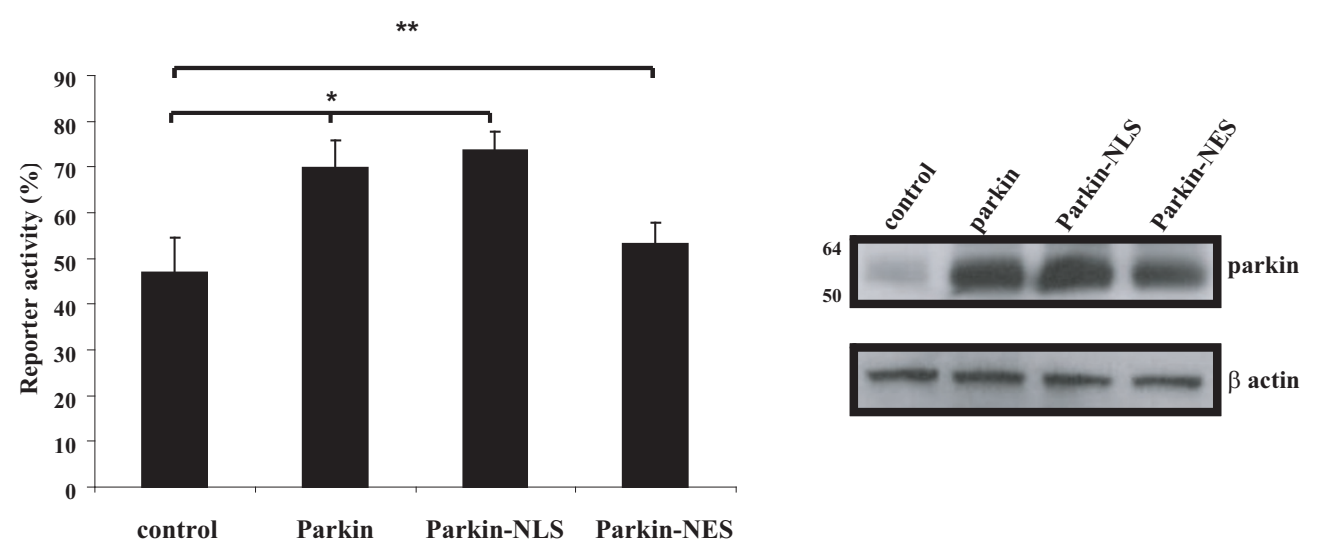

Figure 4

Nuclear localized parkin promotes DNA excision repair. (A) HCR assays showed Parkin facilitates DNA repair of UV induced DNA lesions in SH-SY5Y cells (PTK-Renilla irradiated by UV-C at $250 \mathrm{~J} / \mathrm{m}^{2}$ ). Values are expressed relative to the transfected undamaged reporter, and represent the mean \pm s.d.; $n=3$. Asterisks indicate $P<0.05$ relative to control by ANOVA with post-hoc Student Neumann-Kiels tests. Western blot analysis showed the expression of wild type parkin and parkin Del3-4 mutant. (B) HCR assays showed the ability of wild type Parkin, Parkin-NLS, and Parkin-NES to regulate DNA repair activities. $n=3$. $* P<0.05$, ** $P>0.05$ relative to control by ANOVA with post-hoc Student Neumann-Kiels tests. Western blot analysis showed the expression of wild type parkin, parkin-NLS, and parkin-NES.

ing that nuclear localized parkin is indispensable for the regulation of DNA repair activity.

\section{Discussion}

These findings suggest that a broad range of DNA damaging agents induce nuclear translocation of parkin, including hydrogen peroxide, which induces oxidative base damage, UV irradiation, which induces pyrimidine dimer formation, and etoposide, which induces DNA double strand breaks. It has been shown that parkin-deficient mice show increased 8-oxoguanine in cerebral cortex, and parkin promotes both base and nucleotide excision repair in cultured cells [24]. In addition, parkin associates with PCNA, which mediates DNA excision repair. Thus, parkin may be involved in multiple DNA repair systems, including base and nucleotide excision repair and double strand break repair.

Nuclear translocation of parkin appears to be required, as parkin fused to a nuclear export signal is unable to promote DNA repair. These findings suggest that DNA damage induces nuclear translocation of parkin leading to the 
PCNA interaction and possibly other nuclear proteins involved in DNA repair. These results also replicate the findings of a previous report which showed that oxidative stress can induce nuclear translocation of parkin [27]. The mechanism of nuclear translocation remains to be determined, as parkin does not contain a canonical nuclear localization signal. Parkin could potentially translocate in a complex with PCNA or other DNA repair proteins triggered through DNA damage-mediated signaling. In addition to PCNA, a previous report using yeast two hybrid assays identified a parkin interaction with rad1, a component of the rad9-hus1-rad1 protein complex involved in DNA repair $[28,29]$. These results suggest that parkin promotes DNA repair and protects against genotoxicity, and implicate DNA damage as a potential pathogenic mechanism in parkinsonism.

\section{Competing interests}

The author declares that they have no competing interests.

\section{Authors' contributions}

SYK designed and performed experiments, and prepared the manuscript.

\section{Acknowledgements}

The author thanks Drs. Yihru Fannjiang, Matthew Hass, Tao Lu, and Yahua J. Chen for valuable discussion, and Monlan Yuan, Ying Pan for technical assistance. SY. Kao is a fellow of the Leukemia and Lymphoma Society of America.

\section{References}

I. Kitada T, Asakawa S, Hattori N, Matsumine H, Yamamura $Y$, Minoshima S, Yokochi M, Mizuno Y, Shimizu N: Mutations in the parkin gene cause autosomal recessive juvenile parkinsonism. Nature 1998, 392(6676):605-608.

2. Hedrich K, Eskelson C, Wilmot B, Marder K, Harris J, Garrels J, MeijaSantana $H$, Vieregge $P$, Jacobs $H$, Bressman $S B$, Lang AE, Kann $M$, Abbruzzese G, Martinelli P, Schwinger E, Ozelius LJ, Pramstaller PP, Klein C, Kramer P: Distribution, type, and origin of Parkin mutations: review and case studies. Mov Disord 2004, 19(10): I I46-II57.

3. Cesari R, Martin ES, Calin GA, Pentimalli F, Bichi R, McAdams H, Trapasso F, Drusco A, Shimizu M, Masciullo V, d'Andrilli G, Scambia G, Picchio MC, Alder H, Godwin AK, Croce CM: Parkin, a gene implicated in autosomal recessive juvenile parkinsonism, is a candidate tumor suppressor gene on chromosome 6q25q27. Proc Nat Acad Sci 2003, I 00(I0):5956-5961.

4. von Coelln R, Dawson VL, Dawson TM: Parkin-associated Parkinson's disease. Cell Tissue Res 2004, 3 I 8(1): I75- I84.

5. Zhang Y, Gao J, Chung KK, Huang H, Dawson VL, Dawson TM: Parkin functions as an E2-dependent ubiquitin-protein ligase and promotes the degradation of the synaptic vesicle-associated protein, CDCrel-I. Proc Nat Acad Sci 2000, 97(24): I3354-I 3359.

6. Shimura H, Schlossmacher MG, Hattori N, Frosch MP, Trockenbacher A, Schneider R, Mizuno Y, Kosik KS, Selkoe DJ: Ubiquitination of a new form of alpha-synuclein by parkin from human brain: implications for Parkinson's disease. Science 200I, 293(5528):263-269.

7. Chung KK, Zhang Y, Lim KL, Tanaka Y, Huang H, Gao J, Ross CA, Dawaon VL, Dawson TM: Parkin ubiquitinates the alpha-synuclein-interacting protein, synphilin-I: implications for Lewybody formation in Parkinson disease. Nat Med 200I, 7(I0): I I 44-I I 50 .

8. Imai $Y$, Soda M, Hatakeyama S, Akagi T, Hashikawa T, Nakayama $K$, Takahashi R: CHIP is associated with Parkin, a gene responsi- ble for familial Parkinson's disease, and enhances its ubiquitin ligase activity. Molec Cell 2002, I O(I):55-67.

9. Staropoli JF, McDermott C, Martinat C, Schulman B, Demireva E, Abeliovich A: Parkin is a component of an SCF-like ubiquitin ligase complex and protects postmitotic neurons from kainate excitotoxicity. Neuron 2003, 37(5):735-749.

10. Ko HS, von Coelln R, Sriram SR, Kim SW, Chung KK, Pletnikova O, Troncoso J, Johnson B, Saffary R, Goh EL, Song H, Park BJ, Kim MJ, Dawson VL, Dawson TM: Accumulation of the authentic parkin substrate aminoacyl-tRNA synthetase cofactor, p38/JTV-I, leads to catecholaminergic cell death. J Neurosci 2005, 25(35):7968-7978.

II. Fallon L, Moreau F, Croft BG, Labib N, Gu WJ, Fon EA: Parkin and CASK/LIN-2 associate via a PDZ-mediated interaction and are co-localized in lipid rafts and postsynaptic densities in brain. J Biol Chem 2002, 277(I):486-49I.

12. Lu T, Pan Y, Kao SY, Li C, Kohane I, Chan J, Yankner BA: Gene regulation and DNA damage in the ageing human brain. Nature 2004, 429(6994):883-89I.

13. Rolig RL, McKinnon PJ: Linking DNA damage and neurodegeneration. Trends Neurosci 2000, 23(9):4I7-424.

14. Uberti D, Ferrari Toninelli G, Memo M: Involvement of DNA damage and repair systems in neurodegenerative process. Toxicol Lett. 2003, 39(2-3):99-105.

15. Alam ZI, Jenner A, Daniel SE, Lees AJ, Cairns N, Marsden CD, Jenner $P$, Halliwell $B$ : Oxidative DNA damage in the parkinsonian brain: an apparent selective increase in 8-hydroxyguanine levels in substantia nigra. I Neurochem 1997, 69(3): I | 96-I 203.

16. Simon DK, Lin MT, Zheng L, Liu GJ, Ahn CH, Kim LM, Mauck WM, Twu F, Beal MF, Johns DR: Somatic mitochondrial DNA mutations in cortex and substantia nigra in aging and Parkinson's disease. Neurobiol Aging 2004, 25(I):7I-8I.

17. Migliore L, Scarpato R, Coppede F, Petrozzi L, Bonuccelli U, Rodilla $\mathrm{V}$ : Chromosome and oxidative damage biomarkers in lymphocytes of Parkinson's disease patients. Int J Hyg Environ Health 200I, 204(I):6I-66.

18. Petrozzi L, Lucetti C, Gambaccini G, Bernardini S, Del Dotto P, Migliore L, Scarpato R, Bonuccelli U: Cytogenetic analysis oxidative damage in lymphocytes of Parkinson's disease patients. Neurol Sci 200I, 22(I):83-84.

19. Kao SY, Lemoine FJ, Marriott SJ: Suppression of DNA repair by human $T$ cell leukemia virus type I Tax is rescued by a functional p53 signaling pathway. J Biol Chem 2000, 275(46):35926-3593I.

20. Kao SY, Marriott S): Disruption of nucleotide excision repair by the human T-cell leukemia virus type I Tax protein. J Virol 1999, 73(5):4299-4304.

21. Fallon L, Belanger CM, Corera AT, Kontogiannea M, Regan-Klapisz E, Moreau F, Voortman J, Haber M, Rouleau G, Thorarinsdottir T, Brice $A$, van Bergen En Henegouwen PM, Fon EA: A regulated interaction with the UIM protein EpsI5 implicates parkin in EGF receptor trafficking and $\mathrm{PI}(3) \mathrm{K}-\mathrm{Akt}$ signalling. Nat Cell Biol 2006, 8(8):834-842.

22. Denison SR, Wang F, Becker NA, Schule B, Kock N, Phillips LA, Klein $\mathrm{C}$, Smith DI: Alterations in the common fragile site gene Parkin in ovarian and other cancers. Oncogene 2003, 22(5I):8370-8378.

23. Pawlyk AC, Giasson BI, Sampathu DM, Perez FA, Lim KL, Dawson VL, Dawson TM, Palmiter RD, Trojanowski JQ, Lee VM: Novel monoclonal antibodies demonstrate biochemical variation of brain parkin with age. J Biol Chem 2003, 278(48):48|20-48I 28.

24. Kao SY: Regulation of DNA repair by parkin. Biochem Biophys Res Commun 2009, 382(2):32I-325.

25. Lanford RE, Butel JS: Construction and characterization of an SV40 mutant defective in nuclear transport of $T$ antigen. Cell 1984, 37(3):801-813.

26. Wen W, Meinkoth JL, Tsien RY, Taylor SS: Identification of a signal for rapid export of proteins from the nucleus. Cell 1995 , 82(3):463-473.

27. Um JW, Chung KC: Functional modulation of parkin through physical interaction with SUMO-I. I Neurosci Res 2006, 84(7): 1543-54.

28. Parrilla-Castellar ER, Arlander SJ, Karnitz L: Dial 9-I-I for DNA damage: the Rad9-HusI-RadI (9-I-I) clamp complex. DNA repair 2004, 3(8-9): 1009-1014. 
29. Stelzl U, Worm U, Lalowski M, Haenig C, Brembeck FH, Goehler H, Stroedicke M, Zenkner M, Schoenherr A, Koeppen S, Timm J, Mintzlaff M, Abraham C, Bock N, Kietzmann S, Goedde A, Toksöz E, Droege A, Krobitsch S, Korn B, Birchmeier W, Lehrach H, Wanker EE: A Human Protein-Protein Interaction Network: A Resource for Annotating the Proteome. Cell 2005, I 22(6):957-968.

Publish with Bio Med Central and every scientist can read your work free of charge

"BioMed Central will be the most significant development for disseminating the results of biomedical research in our lifetime." Sir Paul Nurse, Cancer Research UK

Your research papers will be:

- available free of charge to the entire biomedical community

- peer reviewed and published immediately upon acceptance

- cited in PubMed and archived on PubMed Central

- yours - you keep the copyright

Submit your manuscript here:

http://www.biomedcentral.com/info/publishing_adv.asp 